\title{
Chapter 16 \\ Potential Impacts of Climate Change on Forest Habitats in the Biosphere Reserve Vessertal-Thuringian Forest in Germany
}

\author{
Nico Frischbier, Ingolf Profft, and Ulrike Hagemann
}

\subsection{Forest Ecosystems Under a Changing Climate - The Status Quo}

Forests are particularly sensitive to climate change as the long life-span of trees does not allow for rapid adaptation to environmental changes (Profft and Frischbier 2009; Lindner et al. 2010). Climate change considerably influences forest ecosystems through the potential alteration of temperature and precipitation regimes as well as the intensity and frequency of disturbances. Two decades of research have identified drought, heat waves, storm events and forest fires as some of the most relevant impacts for forestry. Climate change can also alter the distribution and life cycle of forest pests, thus modifying the species composition of forest ecosystems (Jönsson et al. 2009; Lindner et al. 2010). In contrast, longer vegetation periods, increased atmospheric $\mathrm{CO}_{2}$ concentration and, regionally, precipitation may positively affect forests and some native species (Zebisch et al. 2005; Bolte et al. 2009; Araujo et al. 2011; Kind et al. 2011; Milad et al. 2011). The sensitivity and vulnerability of forestry, forests and forest habitat types to climate change impacts generally depends on tree species and tree species composition, soil conditions, current climatic conditions and the rate of change.

However, the adaptation potential of forest ecosystems may be restricted by historic and current land use. Since the large-scale forest clearance in medieval times, forests in Central Europe are often restricted to locations where shallow soil, nutrient deficiency, topography, climatic extremes and water deficiency or surplus

\footnotetext{
N. Frischbier $(\varangle) \cdot$ I. Profft

Service and Competence Centre of ThüringenForst,

Jägerstraße 1, DE-99867 Gotha, Germany

e-mail: nico.frischbier@forst.thueringen.de; ingolf.profft@forst.thueringen.de

U. Hagemann

Leibniz-Centre for Agricultural Landscape Research e.V.,

Eberswalder Straße 84, DE-15374 Müncheberg, Germany

e-mail: ulrike.hagemann@zalf.de
} 
prohibited agriculture and settlement. Compared to other biogeographical regions, the adaptation potential of European forests is also limited in terms of genetic and structural diversity, because the cultural landscape is characterised by low biodiversity, lack of spatial connectivity of biotopes and populations, and loss, genetic depletion or specialisation of species, partly due to refuges during and remigration following glaciation. The special situation of forests embedded in the European cultural landscape therefore necessitates profound vulnerability analyses with respect to the expected climatic changes and the subsequent development of substantiated adaptation strategies.

Various approaches have been used to assess the manifold responses of ecosystems and habitats to environmental changes. A basic approach to vulnerability assessment focuses on the climate envelope of a particular species (Box 1981). In combination with relevant climatic and species distribution data, species distribution models (SDM) can be used to derive species absence and presence maps for present and potential future climatic conditions, identifying potential distribution shifts. For silver fir (Abies alba Mill.), currently a rare species in Central Europe, Falk and Mellert (2011) present a risk evaluation based on different SDM's. This approach has also been used for vulnerability assessment of habitat-specific species in Natura 2000 habitats (Harley 2011).

Following a different approach (for details see Chap. 8), Petermann et al. (2007) classified the sensitivity of several habitat types in Germany with respect to pressures (land use, eutrophication), regenerability, spatial distribution, invasion of alien species, dependency on ground water and overflow as well as conservation status. Different levels of sensitivity were expected for habitats with differing biogeographical distribution, dependency on ground water or periodical flooding as well as for habitats under climate change pressure. Azonal forest types such as alluvial forests, bog woodlands and ravine forests were classified as particularly sensitive. The most vulnerable forest type, however, is the montane to alpine acidophilus Picea forest type (Vaccinio-Piceetea-FFH-type 9410, see Lindner et al. 2008; Gartner et al. 2011), which is a major element of the Biosphere Reserve (BR) Vessertal-Thuringian Forest and other mountain ranges in Europe.

\subsection{Our Case Study - The Biosphere Reserve Vessertal-Thuringian Forest (Germany)}

The BR is dominated by the Thuringian Forest, a mountain range characterised by deeply carved valleys. The main ridge features a maximum elevation of $978 \mathrm{~m}$ a.s.l., dropping off to approx. $450 \mathrm{~m}$ a.s.l. As a result of this morphology, the mainly atlantic, moderately cool and moist central mountain climate is modified, resulting in a large variety of local climatic conditions.

The landscape of the BR presents itself as a largely contiguous forest system, with $\sim 90 \%$ forest cover and some small upland meadows in stream valleys and at 

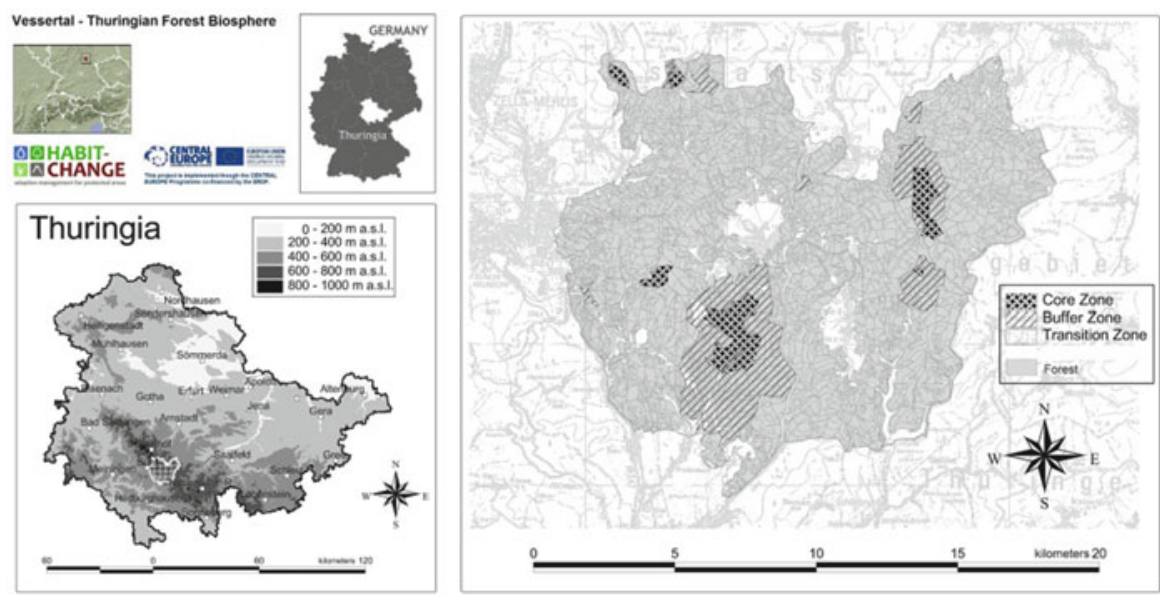

Fig. 16.1 Zoning scheme of the BR Vessertal-Thuringian Forest, located within the montane region of the Federal State of Thuringia in Central Germany

higher elevations. Runoff from the ridge has led to the formation of small raised bogs and feeds a dense network of streams. Although Luzulo-Fagetum and Asperulo-Fagetum beech forests are the predominant potential natural vegetation types, the BR is dominated by single-layer Norway spruce (Picea abies (L.) Karst.) monocultures established following historic overexploitation, calamities and subsequent intensive reforestation. Spruce forest types of higher conservational value are mainly located around treeless ombrotrophic bogs and along the ridge. Except for a handful of small populations, Silver fir - formerly a major component of mixed mountain forests - has disappeared from the area in only a few decades due to air pollution, acid deposition and unsuitable forest management. As most bogs have been drained and subjected to forest management, the restoration and protection of these bogs was the main objective of the BR after its creation in 1979. Today, the BR covers an area of 17.081 ha, with $3.3 \%$ of the area classified as fullyprotected core zones surrounded by $\sim 2.000$ ha of buffer zone (Fig. 16.1). Current debates focus on the enlargement of the BR and the modification of the zones in order to meet the UNESCO requirements.

A total of eight Natura 2000 sites are at least partially located within the BR (Fig. 16.2) and have been mapped and evaluated with respect to forest habitat types and their conservation status (Table 16.1). Presence of the Great Crested Newt (Triturus cristatus Laurenti) and several bat species of Annex II and IV of the Flora-Fauna-Habitat Directive has been confirmed for the BR. The BR is also part of the Special Protection Area (SPA) EU-No. DE 5430-401 under the Birds Directive 79/409/EWG and home to numerous bird species relying on forest habitats, e.g., the Black, Grey-headed and Middle Spotted Woodpecker (Dryocopus martius Linnaeus, Picus conus Gmelin, Dendrocopos medius Linnaeus), the Capercaillie (Tetrao urogallus Linnaeus) and the Black Stork (Ciconia nigra Linnaeus). 
Table 16.1 Evaluation of forest habitat types in the BR Vessertal-Thuringian Forest according to the Habitat Directive

\begin{tabular}{|c|c|c|c|c|c|c|}
\hline \multirow{2}{*}{$\begin{array}{l}\text { Habitat } \\
\text { type }\end{array}$} & \multirow[b]{2}{*}{ Description } & \multirow{2}{*}{$\begin{array}{l}\text { Total area } \\
\text { [ha] }\end{array}$} & \multirow{2}{*}{$\begin{array}{l}\text { Number } \\
\text { of habitats }\end{array}$} & \multicolumn{3}{|c|}{$\begin{array}{l}\text { Conservation } \\
\text { status }\end{array}$} \\
\hline & & & & $\mathrm{A}$ & $\mathrm{B}$ & $\mathrm{C}$ \\
\hline 9110 & Luzulo-Fagetum beech forest & 949.2 & 165 & $(-)$ & 50 & 115 \\
\hline 9130 & Asperulo-Fagetum beech forest & 644.7 & 37 & $(-)$ & 14 & 23 \\
\hline $9180^{\mathrm{a}}$ & $\begin{array}{l}\text { Tilio-Acerion forests of slopes, } \\
\text { screes and ravines }\end{array}$ & 13.4 & 9 & 2 & 7 & $(-)$ \\
\hline $91 \mathrm{D} 0^{\mathrm{a}}$ & Bog woodlands & 75.2 & 5 & $(-)$ & 5 & $(-)$ \\
\hline $91 \mathrm{E} 0^{\mathrm{a}}$ & $\begin{array}{l}\text { Alluvial forests with Alnus glutinosa and } \\
\text { Fraxinus excelsior (Alno-Padion, } \\
\text { Alnion incanae, Salicion albae) }\end{array}$ & 13.8 & 19 & 2 & 16 & 1 \\
\hline 9410 & $\begin{array}{l}\text { Acidophilous Picea forests of the montane to } \\
\text { alpine levels (Vaccinio-Piceetea) }\end{array}$ & 69.3 & 16 & $(-)$ & 6 & 10 \\
\hline
\end{tabular}



Mean annual temperatures (1901-2000) range from 4.0 to $7.5^{\circ} \mathrm{C}$ depending on elevation. However, average temperatures are assumed to have already increased by $0.4-1.0^{\circ} \mathrm{C}$ between 1951 and 2000 . Further temperature increases of $1-3{ }^{\circ} \mathrm{C}$ and 3-4 ${ }^{\circ} \mathrm{C}$ until 2050 and 2071-2100, respectively, are considered as very likely (cf. Frischbier and Profft 2011). The number of hot days and tropical nights will thus increase, while frost and ice days become less frequent. From 1971 to 2000, the forest vegetation period varied between 100 and 150 days per year depending on elevation. It may increase by $12-17$ days until $2041-2070$, and by $35-40$ days by 2071-2100.

The region currently receives $750-1.200 \mathrm{~mm}$ of precipitation per year. Climate monitoring data and climate projections clearly show a shift of the inter-annual precipitation patterns with increasing amounts in autumn and winter and decreasing amounts in spring and summer. This would result in a decreased water supply during the growing season. At the same time, in combination with increased solar radiation, frequent heavy rain events associated with surface runoff and incomplete soil water saturation can result in an 8-14\% increase of the potential evaporation, which further aggravates the situation. The current climatic water balance normalised to the vegetation period ranges from 5 to $351 \mathrm{~m}^{-2}$ month $^{-1}$ (1971-2000). It may decrease by as much as 201 (2041-2070), indicating potential water deficits (Frischbier and Profft 2011).

Although expert opinions about the future frequency and intensity of severe storm events in Central Europe differ widely, there is general agreement on their often disastrous consequences for forests. In 2007, the winter storm 'Kyrill' completely destroyed more than 560 ha of spruce-dominated forests and considerably damaged another 400 ha within the BR. A major spruce bark beetle outbreak occurred as a result of windthrow and breakage and further deteriorated habitat and conservation status. 

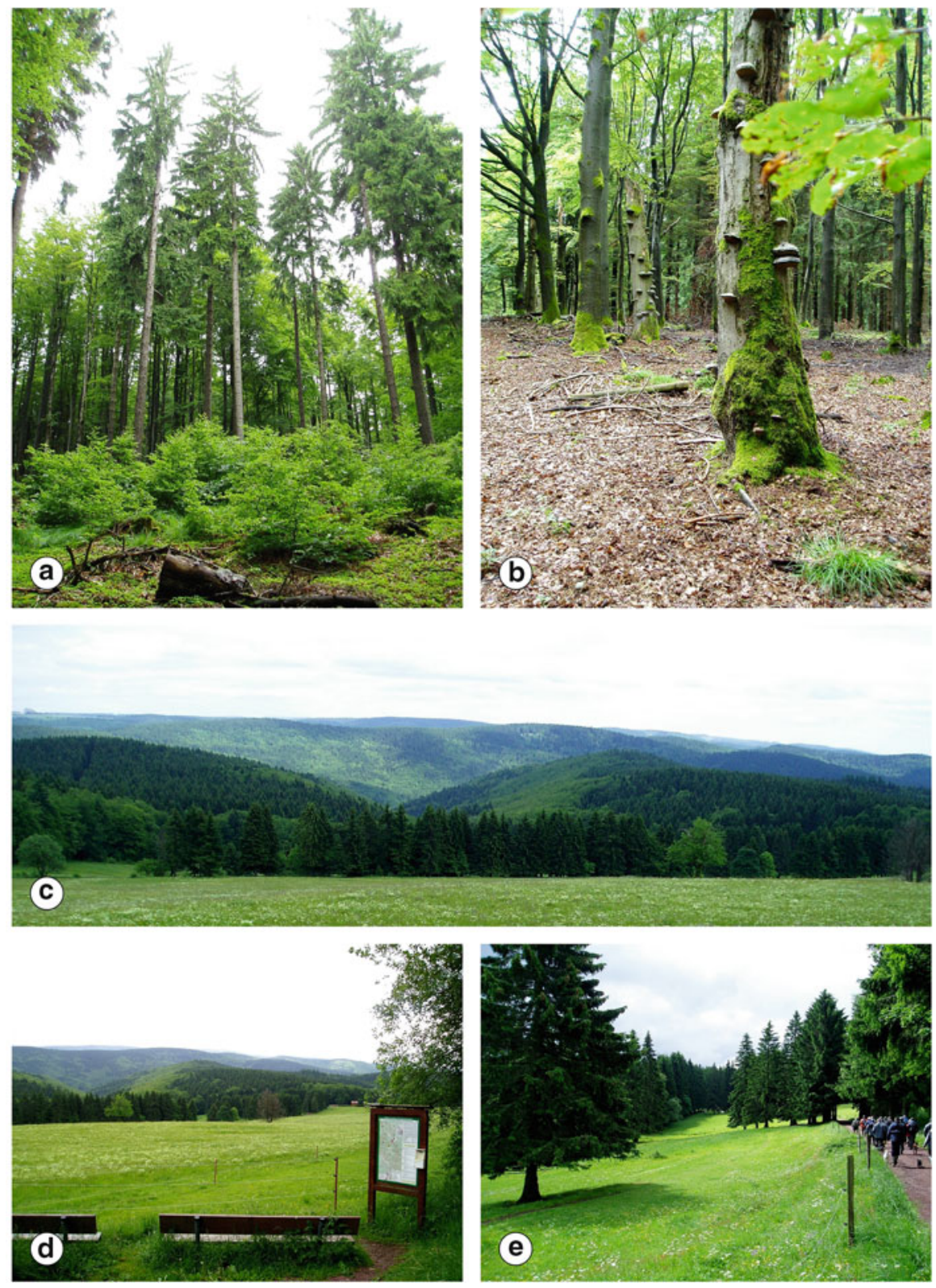

Fig. 16.2 (a-e) Impressions from the BR: (a) Near-natural forests with a mixture of beech and spruce and (b) old-growth forests in the degradation phase offer valuable habitats and microstructures, particularly in gaps and at the highly structured edges. The BR offers a (c) diverse landscape mosaic and $(\mathbf{d}, \mathbf{e})$ adequate infrastructures for tourism and nature recreation 


\subsection{Methods for Identifying Hotspots of Climate Change Impacts - And How to Inform and Engage Stakeholders}

Study objectives were (i) to spatially identify hotspots of climate change impacts in the study area, and (ii) to inform the BR administration and land owners about these impacts and potential adaptation strategies. The study therefore focused on the analysis of the climatic requirements of forest habitat types following the definitions of the EU Habitat Directive and the potential alteration of these habitat types. Moreover, general recommendations for the establishment of near-natural forests in the BR were developed to promote pro-active forest adaptation, which may also positively influence certain habitat types by creating biotope networks.

\subsubsection{Climate Change Impacts on Forest Habitats and their Conservation Status According to the EU Habitat Directive}

Using the terminology of the international nomenclature for the evaluation of forest habitat types (see Ssymank et al. 1998; European Commission 2003; Burkhardt et al. 2004), climate change will modify habitat structure and species composition, increase habitat impairments, and change the presence, frequency and abundance of different forest development phases, of biotopes and over-mature trees and of deadwood. These changes will introduce various levels of diversity depending on the specific type of climatically induced changes:

- Climatically induced, large-scale disturbance (e.g., storm or forest fire).

- Climatically induced, selective small-scale failure of individual tree species, forest structures or forest development phases (e.g., due to drought, frost or species-specific pests).

- Climatically induced, gradual modification of site and environmental conditions (e.g., modified climatic water balance or vegetation period length).

In the case of large-scale wind-induced disturbances, the degree of storm exposure was estimated for the entire BR area by means of GIS analyses (ArcGIS 9.3. spatial analyst). Based on the digital elevation model of Thuringia (resolution of $5 \mathrm{~m}$ ), elevation, slope angle, slope direction and relative exposition compared to the surrounding area were determined for $50 \mathrm{~m}$ grid cells. Grid cells that are not protected from storms by higher topographical elements at distances of 500, 1.000, 1.500 or $2.000 \mathrm{~m}$ were assigned a particularly high degree of exposure in accordance with the Thuringian damage analysis conducted following the 2007 storm 'Kyrill' (Clasen et al. 2008). Regardless of protection from distant topographical elements, forests located on the wind-facing south-westerly slopes featured at minimum a high degree of exposure. 


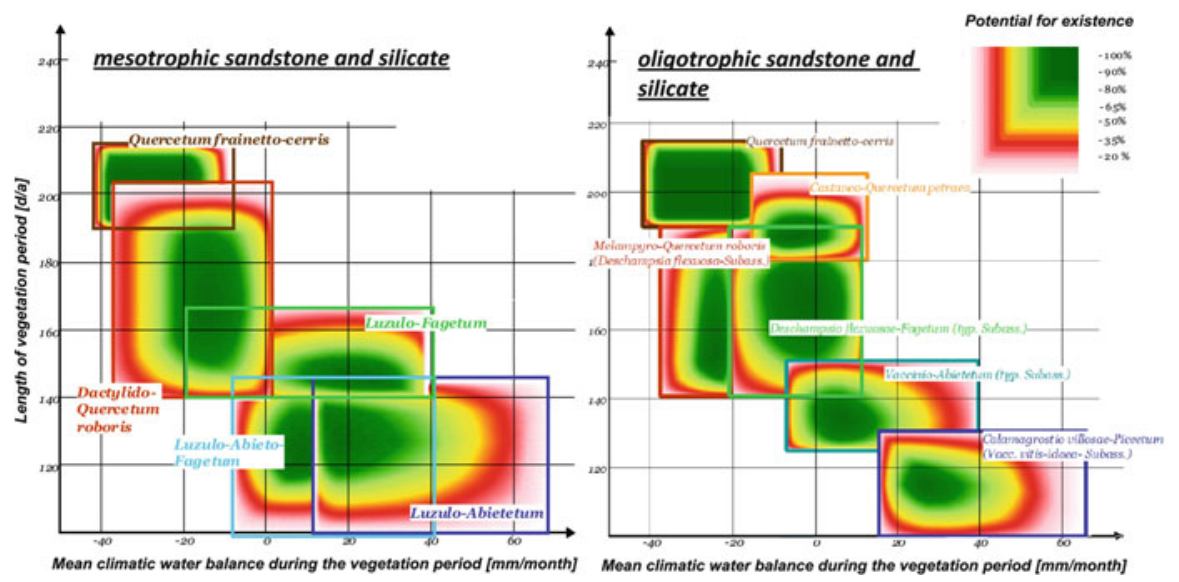

Fig. 16.3 Ecogram for the mesotrophic (left) and oligotrophic (right) nutritional classes of sandstone and silicate soils

In order to estimate and evaluate potential impacts of climate change-induced gradual modifications of site and environmental conditions on the typical species composition of forest habitat types, climate-induced shifts of tree species and related plant associations were simulated. Following the approach by Schlutow and Huebener (2004), ecogram analyses based on more than 17.000 vegetation surveys in Central and Southern Europe (Profft and Frischbier 2009) were used to evaluate the ecological potential of particular forest associations and the associated tree species for the specific site conditions, the current (1971-2000) and the projected (2041-2070, SRES-A1B; IPCC 2000) climate of the study area (Fig. 16.3). Schlutow and Huebener (2004) modelled the existence potential based on the presence and absence data of particular forest associations and the associated tree species as well as the climatic and soil data of the respective vegetation survey. In their species distribution models, the multidimensional niche is derived from numerous environmental factors (e.g., vegetation period, climatic water balance, soil nutrient status, soil substrate, and soil water regime). Schlutow and Huebener (2004) differentiate between the realised and the fundamental niche (cf. Hutchinson 1957) and assign forest ecosystems to the Natura 2000 habitat types according to the German classification scheme (Ssymank et al. 1998). Habitat types covering a wide ecological range were subdivided into sub-associations based on soil type, climate or elevation. In addition, the regionally recommended potential natural vegetation types were used to estimate the potential climatic drift of tree species and related plant associations.

\subsubsection{Involving Stakeholders in the Definition of Forest Conversion Strategies}

In order to avoid ecological and economic damage, the conversion of homogenous to diverse near-natural forests is particularly urgent for vulnerable non-autochthonous 


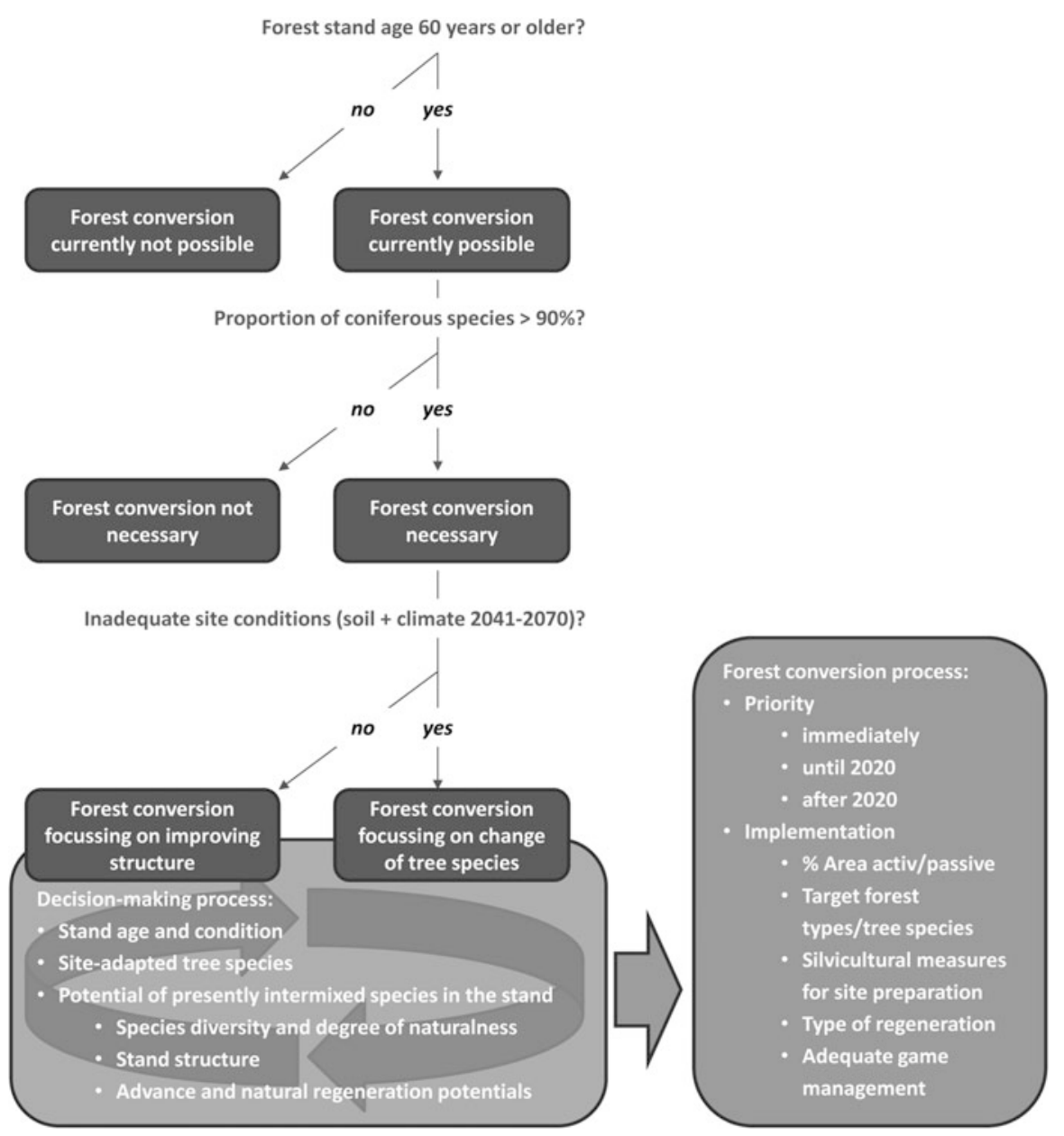

Fig. 16.4 Decision-making scheme for selecting options during the forest conversion process

and poorly structured spruce forests. To evaluate site-specific stand vulnerability based on current and projected climate, middle-aged and mature poorly structured coniferous stands were selected using digital site maps and current forest inventory data (Fig. 16.4). As the central element of an adaptation strategy, site-adapted species composition was then defined for these stands according to the Thuringian recommendations.

The subsequent decision-making process involved joint evaluations and agreements with forest owners, regional stakeholders, the public forest administration and the Thuringian forest authority regarding the short, intermediate and long-term necessity of forest conversion, the self-regulation potential of the selected stands and the silvicultural and financial implementation of forest conversion measures. 


\subsection{Which Climate Change Impacts Are Relevant for Forest Habitats and their Conservation Status According to the EU Habitat Directive?}

\subsubsection{Habitat Change Following Disturbance Events}

Although the frequency of large-scale disturbances within the BR is similar to other regions, spruce-dominated forest associations are nevertheless characterised by a particular vulnerability (Wermelinger 2004; Schütz et al. 2006). Due to the predominant occurrence on windy ridges and adjacent to treeless bog areas as well as the frequent formation of pure stands on peats, gleys, other hydric soils and on blocky or silicate scree material, shallow rooting spruce trees and stands are especially vulnerable for stand-replacing disturbances.

Although these disturbances may create deadwood and valuable micro-habitats (e.g., upturned root plates), the loss of intact stand structures will result in an area loss subject to reporting under the Habitat Directive for the registered forest habitat type 9410. The re-registration of a damaged stand and the subsequent evaluation of its conservation status can only be initiated following forest management measures or the onset of succession. The failure of spruce as dominant species will have a long-lasting negative effect on the criteria related to habitat-typical species composition. Impairments, particularly of the forest floor and the hydrology, are likely. Valuable spatial structures such as the fine-grained mosaic of different forest development phases are often homogenised by large-scale disturbances and thus depreciated. Moreover, the total loss of medium and large-diameter trees due to disturbance events results in the worst rating with respect to spatial structures. If, additionally, snags, biotope and over-mature trees are blown down and more or less entirely lost, forest habitat types may be at risk of general downgrading in terms of habitat structure. Large amounts of disturbance-induced downed deadwood, however, may at most result in a 'good' rating for the deadwood criterion.

In the BR, the Vaccinio-Piceetea habitats located along the bog edges within the FFH areas DE 5330-301 'Schneekopf-Schmücker Graben - Großer Beerberg' and DE 5331-301 'Erbskopf-Marktal und Morast-Gabeltäler' have a particularly high risk of storm damage due to elevation, slope angle, slope direction and relative exposition compared to the surrounding areas. Located in the Northwestern and Eastern parts of the BR, these habitats are mostly left to develop naturally as part of the core zone (Fig. 16.5).

Small-scale, species- or structure-specific failure of individual elements of forest ecosystems may have no or even a positive effect on the evaluation of the conservation status of forest habitat types. This applies particularly to spatially intimate mixtures of different forest development phases and to snags, biotope and overmature trees. The immediate post-disturbance establishment of early successional phases of tree species typical for the respective habitat may also result in improved ratings. Potential impairments due to small-scale disturbances will not be serious. 


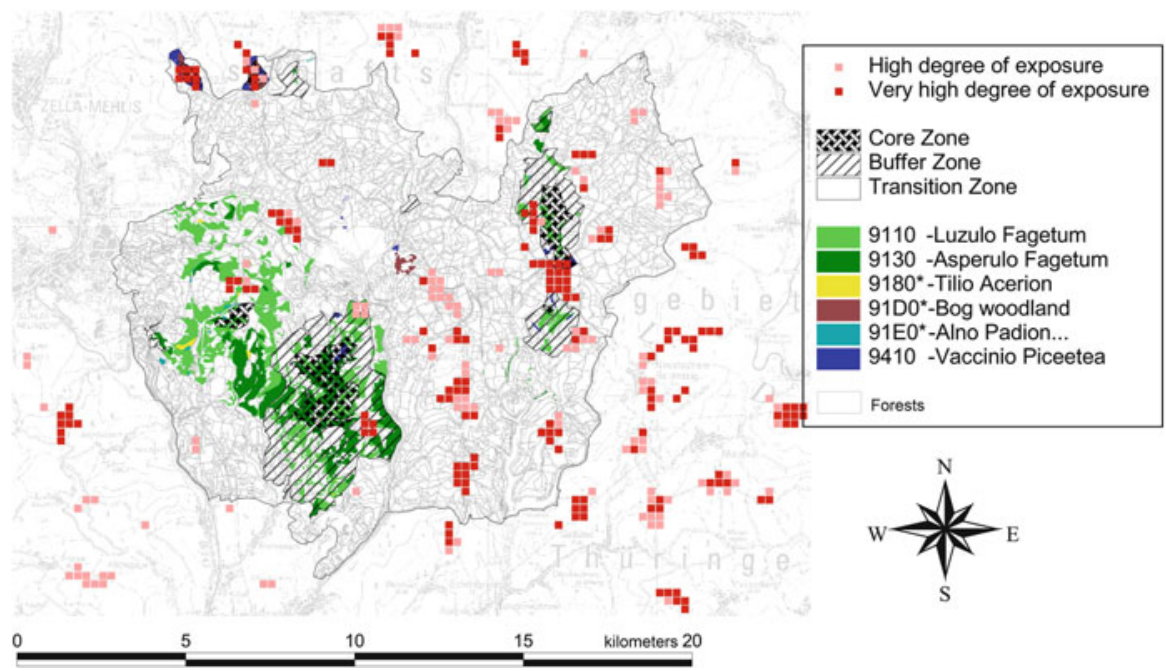

Fig. 16.5 Classification of the area of the BR according to the degree of exposure to storms from indeterminate directions in relation to the BR zones and the distribution of forest habitat types

\subsubsection{Habitat Shifts Due to Gradual Climatic Changes}

Gradual climatic changes may require the reassessment of any given forest habitat type regarding its characteristic site suitability. This applies particularly to bog woodlands (91D0), which are by definition associated with wet organic sites, deep peat layers and high ground-water levels, as well as to alluvial softwood forests (91E0) that lost their functional connection to a flowing water body and are no longer regularly flooded. In both cases, small-scale loss or drift of the respective habitat types is theoretically possible. However, serious changes of the water regime are currently not expected for montane zones characterised by windward weather situations with high amounts of precipitation.

The climate-based evaluation of gradual zonal habitat drifts within the BR relies on the assumption that the current classification is ecologically plausible and correct. However, the first reporting and surveying of the forest habitat types was relatively coarse. For example, Luzulo-Fagetum habitat types are reported for spring-influenced or alluvial azonal stand patches, where habitat types 91E0 and 9180 (Stellario-Alnetum, Carici remotae-Fraxinetum and Ulmo glabrae-Aceretum pseudoplatani) ought to be present.

Highly likely changes of the species composition typical for correctly classified habitat types were evaluated regarding the potential occurrence of plant associations (realised niche) and typical species (fundamental niche) of the respective habitat types (see Fig. 16.6). Depending on the habitat type, 'optimal' and 'good' ratings for species composition are lost if the share of typical species falls below $90 \%$ and $60 \%$, respectively. This is expected for 6 ha of Vaccinio-Piceetea habitats (9410) on wet or moderately moist mesotrophic, slightly to highly skeletal 




Fig. 16.6 Predicted survival probability (red = low, green = very high) for key species of the habitat types Luzulo-Fagetum, Asperulo-Fagetum and Vaccinio-Piceetea for the BR using specific soil conditions and SRES-A1B, ECHAM5 and WETTREG-regionalisation following the approach of Schlutow and Huebener (2004) employed by Profft and Frischbier (2009)

silicate soils if the climatic changes until the middle of the century favour European beech (Fagus sylvatica L.) in terms of temperature and vegetation period length and promote the transition to various sub-associations of the Luzulo-(Abieto-)Fagetum habitat type (9110). On the other hand, transitions from the Luzulo- to the AsperuloFagetum (9130) are highly likely for the eutrophic, highly skeletal silicate soils if the milder climate increases the probability of occurrence for sycamore maple (Acer pseudoplatanus L.) and European ash (Fraxinus excelsior L.) and allows for the establishment of the Galio rotundifolii-Abietetum, Mercuriali-Fagetum and 
Asperulo-Fagetum. Although sessile oak (Quercus petraea Liebl.) is slowly replacing European beech on water-deficient and poorer sites with milder climatic conditions, not even high proportions of oak will cause a perceivable drift in the typical species composition as long as the proportion of beech does not fall below $30 \%$.

\subsubsection{Habitat Impairment Due to Invasive Species}

All aspects of habitat impairment are of special relevance for the evaluation of forest habitat types, because individual ratings are not averaged and the worst rating has a direct impact on the overall rating. The gradually increasing occurrence of non-typical plant species always results in a considerable downgrading of the habitat status. Apart from known species like the Giant hogweed (Heracleum mantegazzianum Somm. u. Lev.), European black pine (Pinus nigra Arnold), Hybrid poplar (Populus x canadensis Moench), Black locust (Robinia pseudoacacia L.) and Canada Goldenrod (Solidago canadensis L.), other invasive species that may potentially become relevant for the BR due to climatic and pedological conditions include the Japanese and the Giant knotweed (Fallopia japonica Houtt. and F. sachalinensis (F. Schmidt) Ronse Decr.), Himalayan balsam (Impatiens glandulifera Royle) and the Bigleaf lupine (Lupinus polyphyllus Lindl.). Although the occurrence of these species is often restricted to forest edges and open areas, these locations may function as initials for future large-scale dispersal. This is of particular importance for alluvial forest habitats (91E0) where the spread of invasive plants, e.g., along the riverbank, needs to be closely monitored and inhibited.

\subsection{Habitat Development by Pro-active Forest Conversion}

Regardless of the BR zoning concept and the designated Natura 2000 sites, structure and site-adapted forest conversion is also required from the perspective of forest owners generating their income mainly from forestry (Fig. 16.7). This approach follows the recommendations of the German Commission for UNESCO (2011) to "intensify efforts to develop innovative approaches for climate change [...] adaptation (including financing models), implement these approaches, [and] adapt management plans." Activities outside of the designated core and buffer area focus on areas which were hitherto managed traditionally under a clearcut management system and are therefore characterised by single-layer stands with few species and low conservational value. The decision-making scheme (cf. Fig. 16.4) allowed for the identification of these forest areas at the level of individual stands in cooperation with the stakeholders. Potential forest conversion areas located near protected areas now need to be assessed with respect to options for habitat development and connectivity (see McComb 2008). To this purpose, the monitoring and management of forest habitat types is an integral component of general forest 

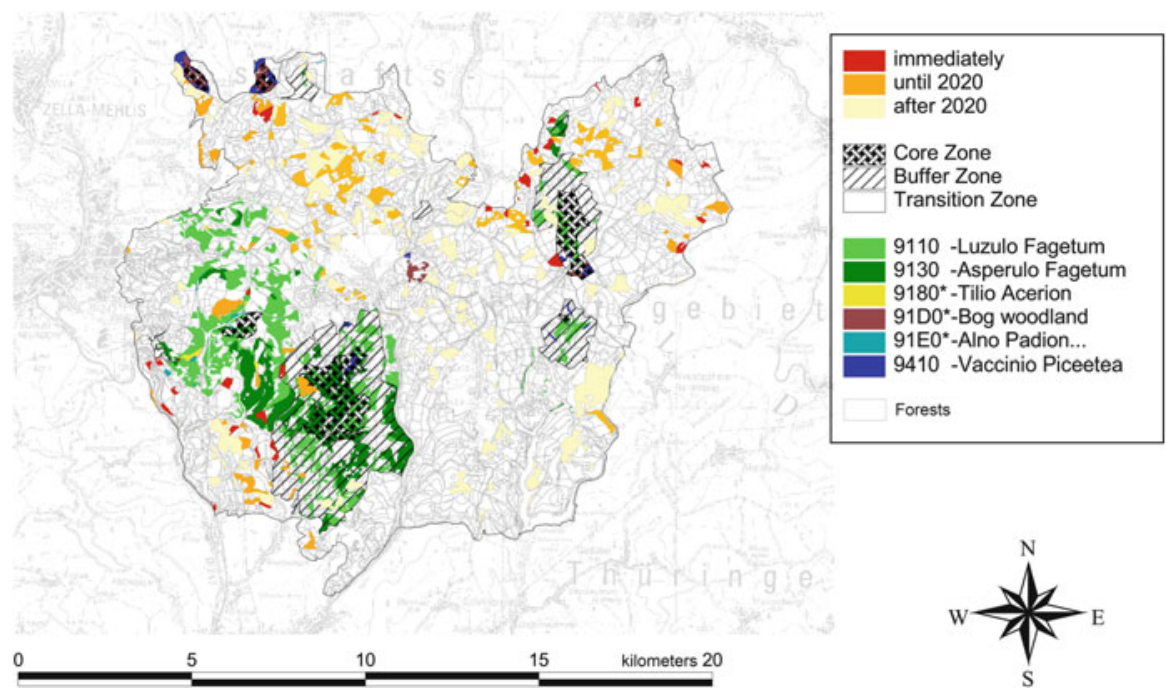

Fig. 16.7 Current agreement on structure and site-adapted forest conversion of single-layer pure coniferous forest stands within the BR. Classes of forest conversion priority (immediately, until 2020, after 2020) were assigned according to the initial situation and general consensus

inventory and management planning. Nevertheless, the concept of near-natural climate-plastic forest management in the region needs to be firmly supported by site-adapted game management, a modern concept for managing deadwood as well as nesting, cavity and biotope trees, the thoughtful use of forest machinery and minimal impairments by other pressures and impacts such as pollution, land consumption and biotope fragmentation.

\subsection{Conclusion}

The general evaluation of the sensitivity and vulnerability of forest habitat types of Petermann et al. (2007) and Harley (2011) has been confirmed for the specific area of the BR. Azonal and spruce-dominated forest habitat types are likely subject to particularly drastic changes associated with climate change. We emphasise that disturbances may not only have disastrous consequences for the habitat status but also for the contribution of forest ecosystems to climate change mitigation. Options for adaptation by management outside of the strictly protected BR core zone mainly involve the restoration and water deregulation of bog areas and along streams in favour of the forest habitat types 91D0 and 91E0 of the EU Habitat Directive.

The ecological gradient of the mixed mountain forest of the montane zone can be ensured by the anticipatory establishment or promotion of site-adapted tree species and structures. Vast areas of poorly structured spruce monocultures still need to be converted into diverse, highly structured mixed stands. Structured forest edges, 
spatial diversity and small patches of different forest development phases also have to be promoted. Although the climate-induced spreading of European beech into the ridge areas of the BR may threaten the typical species composition of the acidophilous Picea forests of the montane zone (9410), the positive effects of an active management in favour of spruce and supplementary intermixed montane species could quickly be offset by disturbances.

Open Access This chapter is distributed under the terms of the Creative Commons Attribution Noncommercial License, which permits any noncommercial use, distribution, and reproduction in any medium, provided the original author(s) and source are credited.

\section{References}

Araujo, M., Alagador, D., Cabeza, M., Nogues-Bravo, D., \& Thuiller, D. (2011). Climate change threatens European conservation areas. Ecology Letters, 14, 484-492. doi:10.1111/j.14610248.2011.01610.x.

Bolte, A., Eisenhauer, D. R., Ehrhart, H. P., et al. (2009). Klimawandel und Forstwirtschaft Übereinstimmungen und Unterschiede bei der Einschätzung der Anpassungsnotwendigkeiten und Anpassungsstrategien der Bundesländer. Landbauforschung - vTI Agriculture and Forestry Research, 4(59), 269-278.

Box, E. O. (1981). Macroclimate and plant forms: An introduction to predictive modelling in phytogeography (Tasks for vegetation science). Boston/London/The Hague: Dr. W. Junk Publishers.

Burkhardt, R., Robisch, F., \& Schröder, E. (2004). Umsetzung der FFH-Richtlinie im Wald. Gemeinsame bundesweite Empfehlungen der Länderarbeitsgemeinschaft Naturschutz (LANA) und der Forstchefkonferenz (FCK). Natur und Landschaft, 7(79), 316-323.

Clasen, C., Frischbier, N., \& Zehner, T. (2008). Ursachenanalyse zum Schadausmaß des Sturmes "Kyrill" in Thüringen. AFZ-DerWald, 14, 746-748.

European Commission. (2003). Interpretation manual of European Union habitats. Brüssel: European Commission, DG XI-Environment.

Falk, W., \& Mellert, K. H. (2011). Species distribution models as a tool for forest management planning under climate change: Risk evaluation of Abies alba in Bavaria. Journal of Vegetation Science, 22, 621-634. doi:10.1111/j.1654-1103.2011.01294.x.

Frischbier, N., \& Profft, I. (2011). Habit-change report 3.2.4 - Report and maps with potential forest habitat changes, Gotha.

Gartner, K., Englisch, M., \& Leitgeb, E. (2011). Effects of climate change on the vulnerability of Norway spruce stands - Soil hydrological constraints for forest management in Austria's lowlands. In M. Bredemeier et al. (Eds.), Forest management and the water cycle: An ecosystem-based approach (Ecological studies, Vol. 212, pp. 127-140). Dordrecht/Heidelberg: Springer. doi:10.1007/978-90-481-9834-4_7.

German Commission for UNESCO. (2011). Dresden Declaration on biosphere reserves and climate change. Conference on the 40th anniversary of UNESCO's MAB programme, Dresden/Germany.

Harley, M. (2011). Climate change and the Natura2000 network: Assessments of species and habitat vulnerability. European conference on biodiversity and climate change, Bonn.

Hutchinson, G. E. (1957). Concluding remarks. Cold Spring Harbor Symposium on Quantitative Biology, 22, 415-427.

IPCC. (2000). IPCC special report: Emissions scenarios - Summary for policymakers. A special report of IPCC Working Group III, Geneva/Switzerland. 
Jönsson, A. M., Appelberg, G., Harding, S., \& Bärring, L. (2009). Spatio-temporal impacts of climate change on the activity and voltinism of the spruce bark beetle, Ips typographus. Global Change Biology, 15, 486-499. doi:10.1111/j.1365-2486.2008.01742.x.

Kind, C., Mohns, T., \& Sartorius, C. (2011). Unterstützung des Managements von Klimarisiken und -chancen. Climate Change 05/2011, Umweltbundesamt, Dessau.

Lindner, M., Garcia-Gonzalo, J., \& Kolström, M. et al. (2008). Impacts of climate change on European forests and options for adaptation. Report to the European Commission DirectorateGeneral for Agriculture and Rural Development, AGRI-2007-G4-06, Joensuu/Finnland.

Lindner, M., Maroschek, M., Netherer, S., et al. (2010). Climate change impacts, adaptive capacity and vulnerability of European forest ecosystems. Forest Ecology and Management, 259, 698-709. doi:10.1016/j.foreco.2009.09.023.

McComb, B. C. (2008). Wildlife habitat management - Concepts and applications in forestry. Boca Raton: CRC Press/Taylor \& Francis Group.

Milad, M., Schaich, H., Bürgi, M., \& Konold, W. (2011). Climate change and nature conservation in Central European forests: A review of consequences, concepts and challenges. Forest Ecology and Management, 261, 829-843. doi:10.1016/j.foreco.2010.10.038.

Petermann, J., Balzer, S., Ellwanger, G., et al. (2007). Klimawandel - Herausforderung für das europaweite Schutzgebietssystem Natura 2000. In S. Balzer, M. Dietrich, \& B. Beinlich (Eds.), Naturschutz und Biologische Vielfalt (Vol. 46, pp. 127-148). Münster: BfN-Schriftenvertrieb im Landwirtschaftsverlag.

Profft, I., \& Frischbier, N. (2009). Forestry in a changing climate - The necessity of thinking decades ahead. In F. Feldmann, D. V. Alford, \& C. Furk (Eds.), Crop plant resistance to biotic and abiotic factors (pp. 66-74). Braunschweig: Deutsche Phytometrische Gesellschaft.

Schlutow, A., \& Huebener, P. (2004). The BERN model: Bioindication for ecosystem regeneration towards natural conditions. UBA Research Report No. 20085221. Dessau: Umweltbundesamt.

Schütz, J. P., Götz, M., Schmid, W., \& Mandallaz, D. (2006). Vulnerability of spruce (Picea abies) and beech (Fagus sylvatica) forest stands to storms and consequences for silviculture. European Journal of Forest Research, 125, 291-302. doi:10.1007/s10342-006-0111-0.

Ssymank, A., Hauke, U., Rückriem, C., \& Schröder, E. (1998). Das europä̈sche Schutzgebietssystem NATURA 2000. BfN-Handbuch zur Umsetzung der Fauna-Flora-Habitat-Richtlinie und der Vogelschutz-Richtlinie (Schriftenreihe für Landschaftspflege und Naturschutz 53). Bonn: Landwirtschaftsverlag.

Wermelinger, B. (2004). Ecology and management of the spruce bark beetle Ips typographus - A review of recent research. Forest Ecology and Management, 202, 67-82. doi:10.1016/j.foreco. 2004.07.018.

Zebisch, M., Grothmann, T., Schröter, D., et al. (2005). Klimawandel in Deutschland Vulnerabilität und Anpassungsstrategien klimasensitiver Systeme. Climate Change 08/2005. Dessau: Umweltbundesamt. 